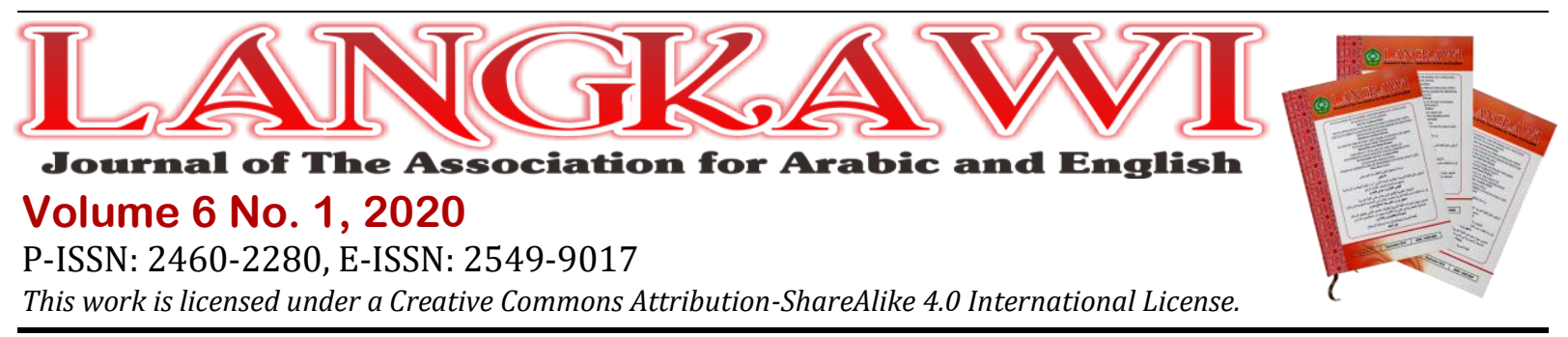

\title{
Meta-discourse Markers in Scientific Journal Articles
}

\author{
Veronica Esti Nugrahani' ${ }^{1}$ Barli Bram ${ }^{2 *}$ \\ ${ }^{1}$ Sanata Dharma University, Yogyakarta, Indonesia. E-mail: veronicaesti@gmail.com \\ 2Sanata Dharma University, Yogyakarta, Indonesia. E-mail: barli@usd.ac.id \\ *(corresponding author)
}

\section{ARTICLE INFO}

Keywords:

interactive meta-discourse marker; interactional metadiscourse marker; scientific journal article; academic writing

How to cite:

Nugrahani, V. E. \& Bram, B. (2020). Meta-discourse Markers in Scientific Journal Articles. Langkawi: Journal of The Association for Arabic and English, 6(1), 1-16.

DOI:

http://dx.doi.org/10.31332/lk w.v6i1.1528

\begin{abstract}
This paper aims to investigate the use of meta-discourse markers in scientific journal articles. Data of this qualitative research consists of meta-discourse markers collected from eight journal articles of a special edition published by LLT Journal: A Journal on Language and Language Teaching. The collected meta-discourse markers used in the journal articles were analyzed using discourse analysis based on ten meta-discourse marker categories. The result indicates that the analyzed journal articles contain 708 meta-discourse markers, with more interactive meta-discourse markers up to 529 occurrences than interactional meta-discourse markers occurring 179 times. Transitions, such as "but" and "thus" take up to 249 occurrences which were the most frequently used meta-discourse marker and boosters, such as "in fact" and "definitely" up to 24 occurrences are the least productive marker. Thus, readers can gain a better understanding of the use of meta-discourse markers when using English. It is expected that English language learners and instructors can benefit from the results of this study, particularly concerning the use of meta-discourse markers in academic writing.
\end{abstract}

\section{Introduction}

Language is the main key to effective communication and interaction. People should be able to use proper language to communicate effectively. Language is used for communication in the form of speaking, writing, and reading. In writing, writers should choose diction wisely to deliver their intensions. They should be able to produce any right kinds of texts. However, creating such good and "reader-friendly" texts remains challenging for writers. Sometimes, they can write completely, but the writing is challenging to follow. Readers tend to have difficulty to "get into the text." Writer-reader interaction in a text is "an integral part of achieving communicative purposes in every discourse community" (Akbarpour, \& Sadeghoghli, 2015: 270). In this context, the role of meta-discourse is crucial. Meta-discourse refers to the concept that writers must learn to "organize texts, engage readers, and signal attitudes to the material and the audience" (Hyland, 2005: ix). By using meta-discourse, it is expected that writers produce more "reader-friendly" texts so that readers can easily follow their writing.

Mina and Biria (2017) mention that the elements of meta-discourse are rhetorical tools that make a text reader-friendly and enable the writer to get the attention of the audience. "Meta-discourse has been an object of research since the 1990s, and due to its importance, a considerable amount of literature has been 
published on the role of meta-discourse in academic writing and research articles" (e.g. Crismore, \& Farnsworth, 1990; Crismore, Markkanen, \& Steffensen, 1993; Abdi, 2002; Dafouz, 2003; Hyland, \& Tse, 2004; Blagojevic, 2004; Simin, \& Tavangar, 2009; Mina, \& Biria, 2017; Sultan, 2011; Kim, \& Lim, 2013; Khedri, Ebrahimi, \& Chan, 2013; Aull, \& Lancaster, 2014; Lee, \& Deakin, 2016). Meta-discourse has already been established as "one of the essential elements of pragmatically effective academic written communication" (Yuksel, \& Kavanoz, 2018: 105).

The terms discourse and discourse analysis have different meanings for scholars in different fields. For linguists, mostly, they define "discourse" as "anything beyond the sentence" (Tannen, Hamilton, \& Schiffrin, 2015: 1). Discourse analysis examines the use of language influenced by relationships between participants and also the effects on social identities and relations (Paltridge, 2012). In other words, it considers the relationship between language and the contexts. From the discourse analysis, it indicates "how people achieve certain communicative goals through the use of language, perform certain communicative acts, participate in certain communicative events and present themselves to others" (Paltridge, 2012: 7). Gee and Handford (2012: 1) define discourse analysis as "the study of language above the level of a sentence, of the ways sentences combine to create meaning, coherence and accomplish purposes." The term discourse analysis is first introduced by (Harris 1952), who defines discourse analysis as a way of analyzing connected speech and writing (cited in Paltridge, 2012).

Jorgensen and Phillips (2002) mention two purposes of discourse analysis. The first one is to figure out how to find a way to fix the meaning of signs and how to make the meaning become conventionalized. The second one is to remove the ambiguity in the texts. From these two aims, it can be inferred that discourse is a tool to make both spoken and written communication meaningful. Meanwhile, Fairclough (1995: 135) proposes three concepts of discourse, namely "language use as social practice, the kind of language used within a specific field, and a way of speaking which gives meanings to experience from a particular perspective." According to Gee and Handford (2012), discourse analysis can deal with one or both of two tasks which are related to utterance-type (general) meaning and situated meaning. Utterance-type (general) meaning involves the study of correlations between form and function in language at the level of utterance-type meanings (general meanings). Meanwhile, situated meaning involves discovering the situationspecific or situated meanings of forms used in specific contexts of use.

Meta-discourse refers to how writers "organize text, engage readers, and signal attitudes to the material and the audience" (Hyland, 2005: ix). Crismore et al. (1993: 40) state that meta-discourse is: "Linguistic material in texts, written or spoken, which does not add anything to the propositional content but intended to help the listener or reader organize, interpret and evaluate the information given."

If meta-discourse markers are removed, the texts will be less personal, less interesting, and less easy to follow (Hyland, 2005) because meta-discourse is a linguistic device to organize the texts, engage readers, and show writers' attitude to their material and their audience (Hyland, 2005). There are two categories of metadiscourse markers, namely interactive and interactional (Hyland, 2005). Based on the two main categories, there exist the following ten subcategories: 
Table 1. Meta-discourse Markers (Hyland, 2005)

\begin{tabular}{|c|c|c|}
\hline Category & Function & Examples \\
\hline Interactive & $\begin{array}{l}\text { Help to guide the reader } \\
\text { through the text }\end{array}$ & Resource \\
\hline 1. Transitions & $\begin{array}{l}\text { Express relations between } \\
\text { main clauses }\end{array}$ & In addition; but; thus; and \\
\hline 2. Frame markers & $\begin{array}{l}\text { Refer to discourse acts, } \\
\text { sequences or slogans }\end{array}$ & $\begin{array}{l}\text { Finally; to conclude; my purpose } \\
\text { is }\end{array}$ \\
\hline $\begin{array}{l}\text { 3. Endophoric } \\
\text { markers }\end{array}$ & $\begin{array}{l}\text { Refer to the information in } \\
\text { other parts of the text }\end{array}$ & Noted above; see Fig; in section 2 \\
\hline 4. Evidentials & $\begin{array}{l}\text { Refer to information from } \\
\text { different texts }\end{array}$ & According to $X ; Z$ states \\
\hline 5. Code glosses & $\begin{array}{l}\text { Elaborate propositional } \\
\text { meanings }\end{array}$ & $\begin{array}{l}\text { Namely; e.g., such as; in other } \\
\text { words }\end{array}$ \\
\hline Interactional & Involve the reader in the text & Resource \\
\hline 6. Hedges & $\begin{array}{l}\text { Withhold commitment and } \\
\text { open dialogue }\end{array}$ & Might; perhaps; possible; about \\
\hline 7. Boosters & $\begin{array}{l}\text { Emphasize certainty or close } \\
\text { dialogue }\end{array}$ & In fact; definitely; it is clear that \\
\hline $\begin{array}{l}\text { 8. Attitude } \\
\text { markers }\end{array}$ & $\begin{array}{l}\text { Express writer's attitude to } \\
\text { the proposition }\end{array}$ & $\begin{array}{l}\text { Unfortunately; I agree; } \\
\text { surprisingly }\end{array}$ \\
\hline 9. Self-mentions & $\begin{array}{l}\text { Explicit reference to the } \\
\text { author (s) }\end{array}$ & I; we; my; me; our \\
\hline $\begin{array}{l}\text { 10. Engagement } \\
\text { markers }\end{array}$ & $\begin{array}{l}\text { Explicitly build a relationship } \\
\text { with the reader }\end{array}$ & Consider; note; you can see that \\
\hline
\end{tabular}

Source: Attarn (2014: 67)

Several researchers have conducted a study concerning meta-discourse markers. A study by Lee and Subtirelu (2015) compares the use of meta-discourse markers by teachers in EAP lessons and university lectures. The results indicate that the use of meta-discourse markers in the classroom is related to the context and content of teaching and learning. Moreover, meta-discourse plays a crucial role in EAP lessons rather than university lectures. The other study conducted by Huh and Lee (2016) explores how meta-discourse features used by 34 undergraduate students to make their persuasive texts. It was found that the students employ some metadiscourse resources but are limited to the rhetorical sophistication.

Yazdani (2017) investigates the differences between Persian and English online headlines using meta-discourse markers. It reveals that Persian fields made more use of the meta-discourse markers than English areas. Meanwhile, a corpusbased linguistic study by Yuksel and Kavanoz (2018) explores the frequencies and usage of meta-discourse markers in Turkish learners of English essays and investigates the differences from native-speaker norms. They find that both novice and expert writers use interpersonal meta-discourse markers more frequently than textual meta-discourse markers. 
Lee and Casal (2014) have conducted a study to examine the meta-discourse markers in the results and discussion sections. However, in their study, Lee and Casal analyzed meta-discourse markers in master's theses. In the present study, the researchers would analyze meta-discourse markers identified in the results and discussion sections of journal articles. Lee and Casal (2014) claim that in the results and discussion section, writer-reader interaction becomes extensive. In this section, writers have to convince readers of claims from the writers' point of view by comparing their findings with previous studies and providing sufficient explanations (Thompson, 2013). Meta-discourse analysis can facilitate "the development of a wellstructured message that engages readers and exhibits the writer's stance toward propositions and the audience of the text" (Alyousef, 2015: 1).

Based on the significant role of meta-discourse in academic writing, particularly in scientific journals, as presented above, this paper aims to investigate the use of meta-discourse markers in scientific journal articles. The articles were analyzed using the meta-discourse marker theory proposed by Hyland (2005). The research question was formulated as follows: What are the meta-discourse marker categories used in scientific journal articles? The focus was on the results and discussion sections of the scientific articles.

\section{Method}

This study is qualitative research since it deals mainly with descriptions, not statistical numbers. The frequency of occurrences is used to support the data analysis. The researchers used discourse analysis to analyze meta-discourse markers identified in the scientific journal articles. Paltridge (2012: 1) mentions that discourse analysis is "an approach to the analysis of language that looks at patterns of the language across texts as well as the social and cultural contexts in which the texts occur." In this study, the researchers analyzed the results and discussion sections. Besides, the data source of this study is eight research articles collected from LLT Journal: A Journal on Language and Language Teaching (LLT Journal, henceforth) published in June 2018 as a special edition (Andang, \& Bram, 2018; Febriyanti, Inderawati, \& Fiftinova, 2018; Hadiyanti, \& Widya, 2018; Indraswari, \& Kuswandono, 2018; Kurniasari, \& Mbato, 2018; Pratiwi, \& Triprihatmini, 2018; Tanjung, 2018; \& Wulandari, \& Ena, 2018). Originally, ten articles were published in this edition. The eight articles above published by LLT Journal were selected to investigate, considering that they contained many examples of meta-discourse markers identified in the preliminary data observation and collection and that they were easily retrievable online. The researchers excluded two articles (the first and the tenth ones) in the special issue because they had no results and discussion sections in the two articles (they were non-research papers).

In collecting the data, the researchers read the eight articles briefly first. Second, the researchers read the articles one by one while collecting the metadiscourse markers focusing on interactive categories, namely transitions, frame markers, endophoric markers, evidential, and code glosses. After completing the interactive category, the researchers moved to the interactional category, which consists of hedges, boosters, attitude markers, self-mentions, and engagement markers. The researchers rechecked the collected data several times to ensure that all 
of the meta-discourse markers had been documented. Third, the researchers made tables consisting of 10 meta-discourse marker categories. Fourth, the researchers calculated the frequencies of each meta-discourse marker category.

Next, the researchers took some steps in analyzing the data. The first step was preparing the data, namely eight journal articles selected from LLT Journal. The data were meta-discourse markers collected from the articles. The next step was coding all of the data. The researchers categorized the meta-discourse markers found in the articles based on the ten meta-discourse marker categories (Hyland, 2005). Then, the researchers provided tables consisting of meta-discourse marker categories and the frequency of occurrence of each category. Lastly, the researchers discussed the findings by providing examples of meta-discourse markers found and gave interpretations.

\section{Findings and Discussion}

From the eight articles in the LLT Journal, all categories of meta-discourse markers were identified. The two main categories were interactive (with subcategories, namely transitions, frame markers, endophoric markers, evidentials, and code glosses) and interactional (with the following subcategories: hedges, boosters, attitude markers, self-mentions, and engagement markers). The findings were presented in Table 2.

Table 2. The Use of Meta-discourse Markers in Journal Articles

\begin{tabular}{lc}
\hline & Interactive \\
\hline Category & Frequency \\
Transitions & 249 \\
Frame markers & 43 \\
Endophoric markers & 97 \\
Evidentials & 99 \\
Code glosses & 42 \\
Total & $\mathbf{5 2 9}$ \\
& \\
\hline & Interactional \\
\hline Category & Frequency \\
Hedges & 57 \\
Boosters & 16 \\
Attitude markers & 44 \\
Self-mentions & 27 \\
Engagement markers & 35 \\
Total & $\mathbf{1 7 9}$ \\
\hline
\end{tabular}

From Table 2, it could be seen that the article authors of the LLT Journal, who were Indonesians, used interactive more than interactional meta-discourse markers. The findings of some other studies in meta-discourse also found more interactive than interactional meta-discourse (Attarn, 2014; Mu, Zhang, Ehrich, \& Hong, 2015; Wang, \& Zhang, 2016). In contrast, some other studies found that their writers tended to use interactional meta-discourse rather than the interactive (Aull \& Lancaster, 2014; Huh \& Lee, 2016; Ho \& Li, 2018). There was a big difference between 
the number of interactive metadiscourse markers, namely 529 resources, and interactional meta-discourse, namely only 179 resources.

\subsection{Interactive markers}

The writers in the LLT Journal used more interactive rather than interactional markers in their articles. Hyland and Tse (2004: 168) explain that "interactive resources are concerned with ways of organizing discourse, rather than experience, to anticipate readers' knowledge and reflect the writer's assessment of what needs to be made explicit about constraining and guiding what can be recovered from the text". Using interactive meta-discourse, the writers tried to organize their articles so that the readers could easily follow the ideas. It made the articles more understandable. The findings indicate all the interactive meta-discourse categories used in the eight articles in the LLT Journal.

\subsubsection{Transitions}

Transitions are when the writers show textual unity by using logical links between ideas (Huh \& Lee, 2016). Hyland (2005) points out that transitions' markers consist of addition, comparison, and consequence. The addition, such as moreover, in addition, and are used for adding arguments or activities (Hyland, 2005). The comparison, including in contrast, on the other hand, meanwhile is for comparing and contrasting events, things, qualities, arguments, and evidence (Hyland, 2005). The consequence, for instance, as a result, therefore, consequently are used for explaining why and how something happens, and drawing conclusions or countering arguments (Hyland, 2005). Similar to several studies (Li, \& Wharton, 2012; Mirshamsi, \& Allami, 2013; Lee, \& Casal, 2014; Alyousef, 2015; Rezaie, \& Lashkarian, 2015; Huh \& Lee, 2016), transitions were the most frequent occurrence in the articles, specifically the interactive meta-discourse markers. Here are the examples of transition markers used by the paper writers in the articles.

(1) The participants' origins were from five universities (two public, three private) in Yogyakarta. Furthermore, based on the 23 items about language attitude...

(2) There is no trend of mono strategy ... However, their different kinds of strategies ... Additionally, the reasons that underline students' preference can be researched for further confirmation.

In examples 1 and 2, the paper writers used the transitions furthermore and additionally to express additional ideas related to the previous ones. Example 1 showed that the writer talked about the main findings of the study after mentioning the general idea of the section. Meanwhile, in example 2, the writer added another activity, namely researching the reasons for students' preference for further confirmation.

(3) The lowest score was 25, the highest score was 75 ... In contrast with the experimental group students, the students in the control group were not exposed to the treatment.

(4) With bullet points and visuals, it offered a simpler way ... On the other hand, some felt bored and sleepy. 
Examples 3 and 4 showed that the writers made use of transitions, particularly the comparison, namely in contrast and on the other hand. These transitions were used for contrasting the particular things of the studies. The writer of the example 3 mentioned that the control group students were different from the experimental group students because they did not receive the treatment. Example 4 indicates the different perceptions of the use of bullet points and visuals. Some students considered that it was helpful to understand complex materials, whereas other students got bored and sleepy.

(5) The English teachers tend to face their problems in TPD in two factors. ... The English teacher tries to find what kind of suitable materials and topics for TPD. Hence, TPD can be followed up to gain the best result.

(6) Both students and lecturers were also communicative and cooperative in the Public Speaking class. Thus, the goal of the Public Speaking class itself was achieved.

Both examples 5 and 6 used transitions to express the consequences. The writers used hence and thus to conclude based on what previous sentences stated. In example 5, the writer concluded that because the English teacher found the suitable materials and topics for TPD, it could be followed up and the best result obtained. Example 6 showed that the public speaking class goal could be achieved because of students' and lecturers' effort in creating communicative and cooperative classroom activities.

\subsubsection{Frame markers}

Cao and $\mathrm{Hu}$ (2014: 19) state that frame markers are "used primarily to organize texts for readers," and Uccelli, Dobbs, and Scott (2013: 45) consider frame markers as "signal the sequence of claims or contrastive positions in the argument." Hyland (2005) elaborates on some functions of a frame marker along with the examples. First, it sequences parts of the text or orders an argument (e.g., first, second, then, next). Second, it can label text stages explicitly (e.g. in sum, to summarize, in brief). Third, it declares discourse goals (e.g. my purpose is, I seek to, o end with). Fourth, it indicates topic shifts (e.g. right, well, let us return to). In general, frame markers are used in the articles to show the shifting topic and keep the flow smooth. From the analysis, the researchers only found 43 frame markers. It could be assumed that the writers rarely utilized frame markers in their articles. The following were the examples of frame markers used by the writers.

(7) The English teachers tend to face their problems in TPD in two factors. The first challenge is the spare time of following TPD... The second challenge is TPD materials.

(8) As this study aims to investigate the language attitudes toward English and Indonesian, it intended to find out the general perspectives about language attitudes ...

(9) In short, lecturers must be creative as it implicates their students' motivation, self-esteem, and learning success (Richards, 2013). The more support lecturers have to help students ...

As could be seen in the examples above, the writers used frame markers which had different functions specifically. In example 7 , the writer elaborated on 
the argument related to the main idea of his/her writing. The writer mentioned two challenges faced by English teachers in TPD orderly. The first and second frame markers were used in example 7 . The writer of example 8 used a frame marker, namely, aim to state the discourse goal. It was mentioned that the study aimed to investigate the language attitudes toward English and Indonesian. Meanwhile, in example 9, the writer used in short to explicitly label the text stages. In this example, the writer wanted to give a stage to simplify the previous sentences mentioned.

\subsubsection{Endophoric markers}

Endophoric markers are used for expressing the relation of certain information mentioned in the different parts of the articles (Huh \& Lee, 2016). Hyland (2005: 51) notes that "these make additional ideational material salient and therefore available to the reader in aiding the recovery of the writer's meanings, often facilitating comprehension and supporting arguments by referring to earlier material or anticipating something yet to come." In other words, the writers used endophoric markers to provide more precise information referring to the different sections of their writing. Based on the data analysis, there was relatively a high frequency of occurrence of endophoric markers. The writers used 97 endophoric markers in their articles. The examples of endophoric markers used by the writers were presented as follows.

(10) From the diagram above, it can be seen that content and performance standards and ICT skills for teaching are wanted by most teachers in joining TPD.

(11) As shown in Table 1, based on the pre-test result, most of the students were categorized in low and failed levels. There were 18 students (45\%) in low level and ...

(12) Apart from the above motivation account of the teachers, ... by English teachers in joining TPD in Indonesia which is discussed in the following section.

From the three examples above, the writers used endophoric markers to mention the specific sections of the articles. In example 10, the writer used an endophoric marker, namely the diagram above referring to a diagram shown previously. The diagram showed that most teachers wanted content and performance standards and ICT skills for teaching. Example 11 showed the use of an endophoric marker, namely Table 1. The writer used this marker to inform the readers that Table 1 contained the results of the pre-test. On the other hand, the writer used the following section. By using this marker, the writer indicated the next section would discuss the challenges faced by English teachers.

\subsubsection{Evidential}

According to Huh and Lee (2016), writers utilize evidential when they mention particular information taken from other texts or sources. Commonly, the writers use evidential to support their proposition (Hyland, 2005). It means that evidential can strengthen writers' opinions in their articles. In this study, there were 99 evidential found in the articles. The examples were provided as follows. 
(13) This finding is in line with the previous research findings of Oh (1992), Sheorey (1999), and Salahshour, et al. (2013) at which students make use of metacognitive strategy ... for their stage of learning language (Graham, 1997; Zare, 2012).

(14) On the contrary, it proves that O'Malley et al. (1985) report about Asian students' learning strategy is memory strategy cannot be fully accepted ...

(15) The students were accommodated to learn topics of public speaking ... It referred to McKinnon's (2000) and McGovern's (1983) theories on video that video was one of teaching and learning aids ...

From the provided examples, it could be seen that the writers used evidential in their articles to support their arguments (in different functions). In example 13, the writer used five different sources to support his/her proposition. The writer stated that the result of his/her study was the same as other studies mentioned in the article. The writer of example 14 mentioned the opponent of his/her study. It seemed that his/her study had different results from previous studies. Example 15 showed that the writer provided a particular theory to strengthen his/her arguments. The writer mentioned his/her claim, followed by a theory from experts.

\subsubsection{Code glosses}

In articles, writers make use of code glosses for providing additional information by explaining, rephrasing, or illustrating (Gholami, Tajalli, \& Shokrpour, 2014). Using code glosses, writers elaborate difficult concepts and terms as well as give examples to explain their idea (Huh \& Lee, 2016). Thus, clarity can be achieved by using code glosses (Cao \& Hu, 2014). The examples of code glosses in the articles were presented as follows.

(16) Frequently, the 20-21 years old students also make use of other strategies, such as social, compensation, cognitive, affective, and memory.

(17) As shown earlier in findings, it can be stated that students use a combination of indirect and direct learning strategies, namely metacognitive, social, and compensation strategies.

(18) The word fuck refers to sexual intercourse activities while the word bitch, which means a female dog, sounds harassing to women when spoken ...

There were four different code glosses used by the writers. For example, 16 writers used such as. This code gloss was used for mentioning other strategies used by 20-21 years old students in learning a language. Meanwhile, the code gloss used in example 17 was namely. It was used for providing further information related to the combination of indirect and direct learning strategies mentioned by the writer earlier. Differently, the writer of example 18 used two code glosses, namely refers to and means. These two code glosses had the same function in the sentences, that is, to clarify a term in the sentence.

\subsection{Interactional markers}

Interactional markers "involve readers in the argument by alerting them to the author's perspective towards both propositional information and readers themselves" (Hyland \& Tse, 2004: 168). Based on the use of interactional markers, it could be seen as the interaction between writers and readers. Interactional markers 
are the writers' engagement and assist writers in building a relationship with readers (Wang \& Zhang, 2016). In this study, the use of interactional markers was less than interactive markers. In total, there were only 179 interactional markers which came from five categories. Those categories were hedges, boosters, attitude markers, selfmentions, and engagement markers. Further elaboration was presented in the following sections.

\subsubsection{Hedges}

Hedges are used by writers when they do not want to show their full commitment to ideas (Akbarpour \& Sadeghoghli, 2015). Sometimes readers might have different opinions related to certain issues. Hence, writers use hedges for increasing the reliability and objectivity of their study (Wang \& Zhang, 2016). By analyzing, there were 57 hedges found in the articles. The frequency of occurrence of hedges was the highest among the other interactional marker categories. It is in line with Rezaie's and Lashkarian's (2015) study that hedges are the most frequently used from the interactional marker category. The following were the examples of hedges used by the writers.

(19) During the debate activity preparations, the teacher helped students to develop various strategies ... situations that they may encounter outside of the classroom.

(20) In the composing phase of the process approach, the students had to describe the person, the place, and the thing ... It means this approach could help the teacher prevent fraud because they focused on the students' writing process.

(21) Besides teaching schedules, the family seems to be the second challenge for the participants to do the TPD program.

The writers made use of hedges to facilitate other possible perceptions from readers. In example 19, the writer used may in the sentence. It showed the writer's uncertainty that students would face different communication situations or not. Example 20 showed the writer's argument related to the process approach. The writer used could claim his/her opinion that the process approach helped teachers to prevent fraud. Meanwhile, the writer of example 21 used seems to state that family was the second challenge for the participants. From the sentence, it could be seen that the writer had an open statement about whether the family was one of the challenges.

\subsubsection{Boosters}

Khedri and Kritsis (2018) point out that boosters are used for avoiding different opinions or possible objections. Writers utilize boosters to show their certainty instead of doubt so that there will be no conflicting arguments (Gholami et al., 2014). The use of boosters showed the writers' authorization to make claims in a firm way. This study identified 16 boosters used by the writers in the articles. From the five interactional categories, boosters had the lowest frequency of occurrence in the articles. The examples of boosters used by the writers were provided as follows.

(22) These results clearly supported our hypothesis that there were no significant differences in the participants' perspectives ... 
(23) Another consideration is that Indonesian class size is large ... In fact, they can do evaluation and self-reflection simultaneously.

(24) From this part, the researchers found that most of the students, seven out of eight students, rated their speaking skills as good.

As could be seen from the examples in 22-24, the writers used three different kinds of boosters for expressing their certainty. The booster in example 22, was clearly. The writer firmly stated that the result of his/her research supported the hypothesis. In example 23, the booster used by the writer was in fact. Based on the sentence, the writer wanted to express his/her strong argument by mentioning a fact. The fact was that students could do both evaluation and self-reflection simultaneously. Example 24 showed the writer's certainty by using found as the booster. The word found strengthened the writer's argument because it was based on the reality discovered through the research.

\subsubsection{Attitude markers}

Attitude markers are used by writers "to express their opinion on the proposition" (Akbarpour \& Sadeghoghli, 2015: 267). In particular, writers used attitude markers to communicate their personal feelings toward the ideas. Generally, attitude can be expressed in the forms of adjectives (e.g. appropriate), verbs (e.g. prefer), and adverbs (e.g. unfortunately) (Huh \& Lee, 2016). In this study, there were 44 attitude markers found in the articles. The following presented examples of attitude markers used by the writers.

(25) The word bloody surprisingly has a high frequency of occurrence $(10,742$ times) for the word bloody is popularly used by the British rather than the American.

(26) It is remarkable to find that no one disagreed, meaning that most participants agreed, to the ideas that PowerPoint presentations assisted the lecturers ...

(27) Students prefer to practice their English whether it involves the practice during the teaching-learning process ...

From the examples, there were three different forms of attitude markers used by the writers. Example 25 showed an adverbial attitude marker, namely surprisingly. The writer expressed his/her feeling because of the shocking result of the study. It was found that the word bloody had a high frequency of occurrence. There was an adjectival attitude marker in example 26 used by the writer. The attitude marker was remarkable. It was used for expressing feelings since an unusual result was found in the study. Meanwhile, for example 27 mentioned a verb prefer to as an attitude marker. The writer expressed his/her feeling by concluding that students had the willingness to practice their English both inside and outside the classroom.

\subsubsection{Self-mentions}

Alyousef (2015) states that self-mentions express writers' presence by using first-person pronouns as well as possessives. The first-person pronouns, such as $I$ and we, whereas possessives including my and our. It is likely that writers also mention his/herself as the writer, the author, or the researcher. A writer uses self- 
mentions to provide information related to his/her position and character (Gholami et al., 2014). This study found out that the writers used 27 self-mentions in their articles. Further explanations based on the examples were presented as follows.

(28) Apart from the above motivation account of the teachers, in this study, the researchers also found some challenges encountered by English teachers ...

(29) After checking the normality and homogeneity of the data, the t-test can be applied. In this study, the writer used paired sample t-test and independent sample t-test. .

Based on the analysis, there were only two kinds of self-mentions used by the writers. The 27 self-mentions consisted of the researcher and the writer only. These two self-mentions had the same function as expressing the writers' position related to their study. In example 28, the writer stated that he/she also found several challenges the English teachers faced. Note that the writer of model 29 mentioned that he/she used a paired sample t-test and independent sample t-test in the study.

\subsubsection{Engagement markers}

According to Khedri and Kritsis (2018: 51), engagement markers help writers "bring readers into discourse, inviting them into argumentations." Commonly, engagement markers are in the forms of "personal pronouns, directives, asides, and interrogative structures" (Khedri \& Kritsis, 2018: 51). By using engagement markers, the writers wanted to include readers in the ideas of their articles. This study found 35 engagement markers in the articles. The following were the examples of engagement markers in the articles along with explanations.

(30) As part of Asian and world community, Indonesian university students should prepare, manage or control and evaluate their learning process.

(31) According to the findings above, it could be assumed that the improvement was caused by the strategy applied.

(32) It is as well interesting to note that less than half of the students got involved in classroom discussions when PPtP was used.

From the examples provided, it could be seen that the writers used different kinds of engagement markers. For example, 30, the writer used should. This engagement marker aimed to invite readers to have the same opinion that Indonesian university students needed to prepare, manage, or control, and evaluate their learning process. In the context, should was used to give advice. In the next example, example 31, the writer used assumed. By using this engagement marker, the writer intended to make readers follow his/her opinion related to the findings of the study. The word assumed implied that statement 31 was true but without any proof. Another engagement marker, in example 32, used by the writer was to note. In the sentence, the writer wanted to ask readers to pay attention to the important findings of his/her study. The discourse marker to note implied that (readers') attention was needed.

\section{Conclusion}

This study investigated the use of meta-discourse markers in scientific journal articles published in a special edition of LLT Journal: A Journal on Language and 
Language Teaching. The results showed that the eight analyzed articles contained transitions, frame markers, endophoric markers, evidentials, code glosses, hedges, boosters, attitude markers, self-mentions, and engagement markers. It means that the article writers used both interactive and interactional meta-discourse markers. In particular, the writers tended to use interactive meta-discourse markers. Based on the findings, the frequencies of occurrences of interactive meta-discourse markers were higher than interactional meta-discourse markers. The most productive metadiscourse marker, with 249 resources, was the transition. Whereas, the subcategory booster became the least productive meta-discourse marker since it had a frequency of 16 only in total.

It is expected that readers can gain a better understanding of the use of metadiscourse markers in writing. For those who engage in the educational field, it is expected that the results of this study can provide them with insights concerning English learning and teaching in general and regarding academic writing in particular. It is essential to make students aware of meta-discourse markers as well as their functions so that the students will be able to apply the markers in their academic writing appropriately.

\section{References}

Abdi, R. (2002). Interpersonal meta-discourse: An indicator of interaction and identity. Discourse Studies, 4(2), 139-145. https:// doi.org/10.1177/14614456020040020101

Akbarpour, M., \& Sadeghoghli, H. (2015). The study on Ken Hyland's interactional model in OUP publications. International Journal of Language and Linguistics, 3(4), 266-270. https://doi.org/10.11648/j.ijll.20150304.21

Alyousef, H. S. (2015). An investigation of meta-discourse features in international postgraduate business students' texts: The use of interactive and interactional markers in tertiary multimodal finance texts. SAGE Open, 5(4), 1-10. https:// doi.org/10.1177/2158244015610796

Andang, K., \& Bram, B. (2018). Swear words and their implications for English language learning-teaching. LLT Journal: A Journal on Language and Language Teaching, 21(Suppl), 43-49.

Attarn, A. (2014). Study of meta-discourse in ESP articles: A comparison of English articles written by Iranian and English native speakers. International Journal of Learning, Teaching and Educational Research, 5(1), 63-71.

Aull, L. L., \& Lancaster, Z. (2014). Linguistic markers of stance in early and advanced academic writing: A corpus-based comparison. In Written Communication (Vol. 31). https:// doi.org/10.1177/0741088314527055

Blagojevic, S. (2004). Meta-discourse in academic prose: A contrastive study of academic articles written in English by English and Norwegian native speakers. Kalbu Studijos, (5), 60-67. Retrieved from https://www.kalbos.lt/zurnalai/05_numeris/08.pdf

Cao, F., \& Hu, G. (2014). Interactive meta-discourse in research articles: A comparative study of paradigmatic and disciplinary influences. Journal of Pragmatics, 66, 15-31.

Crismore, A. \& Farnsworth, R. (1990). Meta-discourse in popular and professional science discourse. In W. Nash (Ed.), The writing scholar: Studies in academic 
discourse (pp. 118-136). Newbury Park, CA: Sage Publications.

Crismore, A., Markkanen, R., \& Steffensen, M. S. (1993). Meta-discourse in persuasive writing: A study of texts written by American and Finnish university students. In Written Communication (Vol. 10). https:/ / doi.org/10.1177/0741088393010001002

Dafouz-Milne, E. (2003). Meta-discourse revisited: A contrastive study of persuasive writing through professional discourse. Estudios Ingleses de La Universidad Complutense, 11, 29-52. https://doi.org/10.5209/rev_EIUC.2003.v11.8792

Fairclough, N. (1995). Critical discourse analysis. London: Longman.

Febriyanti, R., Inderawati, R., \& Fiftinova, F. (2018). Enhancing descriptive writing achievement by applying process approach through environmental observation. LLT Journal: A Journal on Language and Language Teaching, 21(Suppl), 21-32.

Gee, J.P., \& Handford, M. (Eds.). (2012). The Routledge handbook of discourse analysis. New York: Routledge.

Gholami, M., Tajalli, G., \& Shokrpour, N. (2014). An investigation of meta-discourse markers in English medical texts and their Persian translation based on Hyland's model Mehrnaz. European Journal of English Language and Literature Studies, 2(2), $1-41$.

Hadiyanti, K., \& Widya, W. (2018). Analyzing the values and effects of powerpoint presentations. LLT Journal: A Journal on Language and Language Teaching, 21(Suppl), 87-95.

Harris, Z. (1952). Discourse analysis. Language, 28, 1-30.

Ho, V., \& Li, C. (2018). The use of meta-discourse and persuasion: An analysis of first year university students' timed argumentative essays. Journal of English for Academic Purposes, 33, 53-68. https:/ / doi.org/10.1016/j.jeap.2018.02.001

Huh, M. H., \& Lee, I. H. (2016). On the use of meta-discourse in EFL undergraduate $\begin{array}{llll}\text { student } \quad \text { writing. } & \text { 2nglish }\end{array}$ https:// doi.org/10.15858/engtea.71.3.201609.99

Hyland, K. \& Tse, P. (2004). Meta-discourse in academic writing: A reappraisal. Applied Linguistics, 25(2), 156-177.

Hyland, K. (2005). Meta-discourse: Exploring interaction in writing. London: Continuum.

Indraswari, V., \& Kuswandono, P. (2018). English teachers' motivation and challenges in vocational high school in Yogyakarta. LLT Journal: A Journal on Language and Language Teaching, 21(Suppl), 96-104. Retrieved from https://ejournal.usd.ac.id/index.php/LLT/article/view/1197

Jorgensen, M., \& Phillips, L. (2002). Discourse analysis as theory and method. London: Sage Publication.

Khedri, M., \& Kritsis, K. (2018). Meta-discourse in applied linguistics and chemistry research article introductions. Journal of Research in Applied Linguistics, 9(2), 4773.

Khedri, M., Ebrahimi, S. F. \& Chan, S. H. (2013). An exploration of interactive metadiscourse markers in academic research article abstracts in two disciplines. Discourse Studies, 15(3), 319-331.

Kim, C.L., \& Lim, J. M. H. (2013). Meta-discourse in English and Chinese research article introductions. Discourse Studies, 15(2), 129-146. 
Kurniasari, M., \& Mbato, C. (2018). Indonesian students' language attitudes towards Indonesian and English through education and working frame. LLT Journal: A Journal on Language and Language Teaching, 21(Suppl), 69-86. Retrieved from https://e-journal.usd.ac.id/index.php/LLT/article/view/1184

Lee, J. J., \& Subtirelu, N. C. (2015). Meta-discourse in the classroom: A comparative analysis of EAP lessons and university lectures. English for Specific Purposes, 37, 52-62.

Lee, J.J., \& Casal, J. E. (2014). Meta-discourse in results and discussion chapters: A cross-linguistic analysis of English and Spanish thesis writers in engineering. System, 46, 39-54.

Lee, J.J., \& Deakin, L. (2016). Interactions in L1 and L2 undergraduate student writing: Interactional meta-discourse in successful and less-successful argumentative essays. Journal of Second Language Writing, 33, 21-34.

Li, T., \& Wharton, S. (2012). Meta-discourse repertoire of L1 Mandarin undergraduates writing in English: A cross-contextual, cross-disciplinary study. Journal of English for Academic Purposes, 11, 345-356.

Mina, K.G., \& Biria, R. (2017). Exploring interactive and interactional meta-discourse markers in discussion sections of social and medical science articles. International Journal of Research in English Education, 2(4), 11-29.

Mirshamsi, A. \& Allami, H. (2013). Meta-discourse markers in the discussion/conclusion section of Persian and English master's theses. The Journal of Teaching Language Skills, 5(3), 23-40.

$\mathrm{Mu}, \mathrm{C} ., Z^{2}$ ang, L.J., Ehrich, J., \& Hong, H. (2015). The use of meta-discourse for knowledge construction in Chinese and English research articles. Journal of English for Academic Purposes, 20, 135-148.

Noorian, M., \& Biria, R. (2017). Interpersonal meta-discourse in persuasive journalism: A study of texts by American and Iranian EFL columnists. Journal of Modern Languages, 20(1), 64-79.

Paltridge, B. (2012). Discourse analysis: An introduction (2nd ed). New York: Bloomsbury.

Pratiwi, S., \& Triprihatmini, V. (2018). Students' perception on the use of video to assess performances in public speaking class. LLT Journal: A Journal on Language and Language Teaching, 21(Suppl), 33-42. Retrieved from https://ejournal.usd.ac.id/index.php/LLT/article/view/1177

Rezaie, M., \& Lashkarian, A. (2015). The use of meta-discourse markers in TESOL and medical research articles. International Journal of English and Education, 4(4), 345-356.

Simin, S., \& Tavangar, M. (2009). Meta-discourse knowledge and use in Iranian EFL writing. The Asian EFL Journal Quarterly, 11(1), 230-255.

Sultan, A. H. J. (2011). A contrastive study of meta-discourse in English and Arabic linguistics research articles. Acta Linguistica, 5, 28-41.

Tanjung, F. (2018). Language learning strategies in English as a foreign language classroom in Indonesian higher education context. LLT Journal: A Journal on Language and Language Teaching, 21(Suppl), 50-68. Retrieved from https://ejournal.usd.ac.id/index.php/LLT/article/view/966

Tannen, D., Hamilton, H.E., \& Schiffrin, D. (Ed.). (2015). The handbook of discourse 
analysis. Oxford: John Wiley \& Sons, Inc.

Thompson, P. (2013). Thesis and dissertation writing. In B. Paltridge \& S. Starfield (Ed.), The handbook of English for specific purposes (pp. 283-299). West Essex: Wiley-Blackwell.

Uccelli, P., Dobbs, C. L., \& Scott, J. (2013). Mastering academic language organization and stance in the persuasive writing of high school students. Written Communication, 30(1), 36-62.

Wang, L., \& Zhang, Y. (2016). An analysis of meta-discourse in the abstracts of English academic papers. Global Journal of Human-Social Science, 16(9), 9-16.

Wulandari, A., \& Ena, O. (2018). Using debate activities to develop Indonesian high school students' speaking skills. LLT Journal: A Journal on Language and Language Teaching, 21(Suppl), 12-20. Retrieved from https://ejournal.usd.ac.id/index.php/LLT/article/view/1168

Yazdani, A. (2017). Comparing meta-discourse markers employed in English and Persian online headlines. International Journal of Research Studies in Language Learning, 6(4), 91-97. https:/ / doi.org/10.5861/ijrsll.2016.1554

Yuksel, H.G., \& Kavanoz, S. (2018). Dimension of experience: Meta-discourse in the texts of novice non-native, novice native and expert native speaker. Advances in Language and Literary Studies, 9(3), 104-112. 